\title{
ARTIKELEN
}

\section{Het aanpassingsdilemma online: een verkennend onderzoek naar extreemrechts op social media}

\author{
Robby Roks \& Jolijn van der Schoot
}

Wetenschappelijk onderzoek naar offline manifestaties van extreemrechts wordt bemoeilijkt door het zogenaamde aanpassingsdilemma: individuen en groepen die hun extreemrechtse ideologie verhullen of matigen om sancties of stigmatisering te voorkomen. Al sinds het ontstaan van het internet wordt er door extreemrechtse groeperingen en individuen gebruik gemaakt van digitale kanalen en middelen om een omgeving van gelijkgestemden te vinden waar zij openlijk uit kunnen komen voor hun extreemrechtse ideeën en minder maatschappelijke weerstand ervaren dan offline. In toenemende mate wordt daarbij niet langer gebruik gemaakt van specifieke websites en fora met rechts-extremistische content of deep- en darkwebpagina's, maar ook van mainstream-socialmediaplatforms zoals Twitter en Facebook. In deze bijdrage wordt verslag gedaan van een studie naar de wijze waarop drie Nederlandse rechts-extremistische groeperingen, te weten de NVU, Pegida en Voorpost, gebruik maken van diverse sociaImediaplatforms in het jaar 2017. Onze resultaten laten zien dat deze extreemrechtse groeperingen social media gebruiken om hun ideologie uit te dragen, een groepsidentiteit te construeren en op te roepen tot (democratische) vormen van verzet. Daarnaast illustreert deze bijdrage dat het aanpassingsdilemma van extreemrechts ook een digitale equivalent kent. De extreemrechtse ideeën worden op social media niet per definitie verhuld, maar wel aangepast aan de gestelde eisen van de digitale omgeving. Het gaat hierbij niet om 'impression management' in termen van het uitdragen van identiteit, maar eerder om 'content management' om ervoor te zorgen dat de extreemrechtse ideologieën via social media blijvend kunnen worden uitgedragen.

\section{Inleiding}

$\mathrm{Na}$ een periode van neergang lijkt er in Nederland sinds 2014 een lichte opleving van het rechts-extremisme, ${ }^{1}$ zo blijkt uit een recente publicatie van de Algemene Inlichtingen- en Veiligheidsdienst (AIVD, 2018). Wetenschappelijk onderzoek naar extreemrechts wordt bemoeilijkt door het zogenaamde aanpassingsdilemma: individuen en groepen die hun extreemrechtse ideologie verhullen of matigen om sancties of stigmatisering te voorkomen (Van Donselaar, 1991, 15-17; Van der Valk \& Wagenaar, 2010, 30). Diverse internationale studies schetsen echter dat rechts-extremistische groepen en individuen al sinds het ontstaan van het

1 De termen extreemrechts en rechts-extremisme worden in deze bijdrage inwisselbaar gebruikt. 
internet gebruik maken van digitale kanalen en middelen om een omgeving van gelijkgestemden te vinden waar zij openlijk uit kunnen komen voor hun extreemrechtse ideeën en minder maatschappelijke weerstand ervaren dan offline (voor een overzicht, zie Caiani \& Kröll, 2015; Valasik \& Reid, 2018). De verhulling van extreemrechtse identiteiten en ideologieën lijkt op basis van de beschikbare wetenschappelijke literatuur dan ook vooral van toepassing te zijn op offline interacties en uitingen.

Ondanks dat zowel de AIVD (2018) als de Nationaal Coördinator Terrorismebestrijding en Veiligheid (NCTV, 2018a) in zijn meest recente publicatie verwijst naar de aanwezigheid van extreemrechts op social media, is er nog weinig bekend over de manier waarop extreemrechtse groeperingen in Nederland gebruik maken van socialmediaplatforms. Om een bijdrage te leveren aan deze kennis doen we in dit artikel verslag van een verkennende studie naar het gebruik van social media door drie Nederlandse extreemrechtse groeperingen in het jaar 2017, te weten de Nederlandse Volksunie (hierna: de NVU), Pegida en Voorpost. ${ }^{2}$ Deze overkoepelende doelstelling wordt geoperationaliseerd in een tweetal specifieke onderzoeksvragen. De eerste onderzoeksvraag luidt: hoe maken de NVU, Pegida en Voorpost gebruik van social media in 2017? De tweede onderzoeksvraag richt zich op de vraag in hoeverre er gesproken kan worden van online extremisme op de officiële socialmedia-accounts van de NVU, Pegida en Voorpost. Met online extremisme wordt verwezen naar 'a form of cyberviolence characterized by the use of digital platforms to express hatred towards a collective on the basis of race, ethnicity, gender, gender identity, sexual orientation, national origin, religion, or some other group characteristic' (Hawdon e.a., 2018, 2). Voor het beantwoorden van deze laatste onderzoeksvraag kijken we naar overeenkomsten en verschillen in de manier waarop online extremisme tot stand komt op socialmedia-accounts van de drie verschillende groeperingen, zowel in de berichten als in de reacties op deze officiële accounts. Met deze vraag proberen we inzicht te krijgen in hoeverre het eerder genoemde aanpassingsdilemma rondom extreemrechtse ideologieën ook online valt waar te nemen.

Dit artikel is als volgt opgebouwd. Allereerst geven we een kort overzicht van de wetenschappelijke literatuur over extreemrechts in Nederland en online rechtsextremisme. Na een bespreking van de methodologische opzet van dit onderzoek presenteren we de belangrijkste resultaten van deze studie. We besluiten deze bijdrage met een reflectie op de theoretische en maatschappelijke relevantie van de resultaten van deze verkennende studie.

\section{Overzicht van de wetenschappelijke literatuur}

\section{Extreemrechts in Nederland}

In de zoektocht naar een definitie van extreemrechts is de conclusie getrokken dat het fenomeen te ingewikkeld is om te definiëren en dat daardoor geen enkele

2 De keuze voor deze drie groeperingen lichten we nader toe in de methodologische verantwoording. 
definitie sluitend ${ }^{3}$ is (voor een overzicht, zie Van Donselaar, 2009; De Waele, 2013). Onder extreemrechtse groeperingen verstaan we in deze bijdrage, in navolging van de jaarlijkse rapportage 'Racisme, antisemitisme en extreemrechts geweld in Nederland' (Tierolf e.a., 2018, 6), organisaties met een ideologie die wordt gekenmerkt door '(varianten van) oriëntatie op het "eigene", (varianten van) afkeer van het "vreemde", waarbij een onderscheid tussen het "eigene" en het "vreemde" primair gebaseerd is op etnische verschillen'.

De afbakening van het 'eigene' zit, ondanks dat dit op diverse manieren wordt vormgegeven, altijd in het hart van de ideologie van extreemrechts en kent over het algemeen een etnisch aspect. Ook het 'vreemde' heeft een centrale plek en afhankelijk van de ideologische achtergrond, context en tijdsperiode wordt dit etnisch 'vreemde' op verschillende manieren geformuleerd: van biologisch afgebakende groepen zoals 'zwarten' of 'joden' tot meer nationaal, etnisch of religieus afgebakende groepen als 'Marokkanen', 'buitenlanders', 'asielzoekers' of 'moslims' (Wagenaar, 2017, 35). Ondanks deze verschillen wordt de kern gevormd door de afbakening van het 'vreemde' door datgene wat het 'eigene' niet is (Wagenaar, 2016, 42).

Sinds het einde van de Tweede Wereldoorlog is het begrip extreemrechts emotioneel en moreel beladen (Moors e.a., 2009, 82), omdat het verschijnsel associaties oproept met massamoord, vernietiging en verovering (Van der Valk \& Wagenaar, 2010, 29). Na 1945 is er sprake geweest van een politiek en sociaal isolement van extreemrechtse groeperingen, hetgeen gepaard ging met allerlei repressiemaatregelen. Het is een overlevingsstrategie van extreemrechts geworden om de ideologische opvattingen te verhullen en een gematigde of aangepaste boodschap te verspreiden. Het verhullen van deze eigenlijke ideeën noemt Van Donselaar (1991, 15-17) het aanpassingsdilemma. Dit dilemma heeft betrekking op negatieve reacties waardoor extreemrechtse formaties hun eigen identiteit matigen of verhullen om sancties of stigmatisering te voorkomen (Van der Valk \& Wagenaar, 2010, 30). Van der Valk en Van der Schans $(2011,12)$ stellen dat veel extreemrechtse organisaties zich 'onder invloed van het aanpassingsdilemma "backstage" vaak in mindere mate laten leiden door de repressieve dreiging dan "frontstage". Het aanpassingsdilemma zou resulteren in verschillen tussen 'frontstage en backstage performances' en 'achter de schermen' zou de 'ware identiteit' beter zichtbaar zijn ${ }^{4}$ (Van der Valk \& Van der Schans, 2011, 12).

De termen frontstage en backstage zijn schatplichtig aan het werk van Erving Goffman, die in The presentation of self in everyday life (1959) de manier analyseert waarop het individu in alledaagse situaties zichzelf en zijn activiteiten presenteert

3 Mudde (1995, 218-219) heeft een patroon ontdekt in verschillende definities van extreemrechts, waarbij vijf kenmerken veelvuldig worden benoemd, namelijk: nationalisme, racisme, xenofobie, antidemocratie en de sterke staat. Daarnaast constateren Moors en collega's (2009, 87) dat er enkele elementen zijn die de laatste vijf decennia telkens terugkeren, namelijk: pluriformiteit (organisaties komen en gaan, fuseren en splitsen), onderlinge verdeeldheid en versplintering, geringe organisatorische stabiliteit en pogingen om tot meer eenheid te komen.

4 Onderzoek naar racisme brengt onder de noemer van 'two-faced racism' (Picca \& Feagin, 2007) een vergelijkbare dynamiek naar voren, waarbij eveneens gebruik wordt gemaakt van het dramaturgisch perspectief van Goffman. 
aan anderen. Uit de toepassing van het dramaturgisch idioom van Goffman kan worden afgeleid dat het in kaart brengen en duiden van de overtuigingen van extreemrechtse groeperingen of individuen geen sinecure is. Zo stellen Van der Valk en Van der Schans $(2011,12)$ dat waarnemers, in het bijzonder onder invloed van het aanpassingsdilemma, 'alleen een gefilterde, gematigde boodschap' te zien krijgen en dat 'het definiëren en afbakenen op basis van alleen de openbare boodschap van potentieel extreemrechtse organisaties onvoldoende houvast biedt'.

\section{Online (rechts)extremisme}

Deze 'onzichtbaarheid' van extreemrechtse identiteiten en ideologieën, waar meerdere auteurs naar verwijzen in Nederland (Van Donselaar, 1991, 15; Moors e.a., 2009, 87; Van der Valk \& Wagenaar, 2010, 30; Van der Valk \& Van der Schans, 2011, 12), lijkt echter vooral van toepassing te zijn op offline interacties en uitingen. Online komen groeperingen en individuen doorgaans expliciet uit voor hun extreemrechtse overtuigingen. Zo beschrijven De Koster en Houtman $(2008,1171)$ in hun analyse van Stormfront het forum als 'a stage for the display of extreme right identities'. Volgens de auteurs kan participatie op het forum voor veel van de reguliere bezoekers begrepen worden 'as a reaction to negative experiences because of a "spoiled identity" - as a reaction to stigmatization' (De Koster \& Houtman, 2008, 1171). Behalve specifieke websites en fora met rechtsextremistische content, zoals Stormfront (Bowman-Grieve, 2009), kunnen deepen darkwebpagina's en ongemodereerde fora, zoals 4chan, 8chan en Reddit (Hawley, 2017; Nagle, 2017), en mainstream-socialmedia als Facebook (Pauwels e.a., 2014; Ben-David \& Matamoros-Fernández, 2016) fungeren als een vergelijkbaar podium voor extreemrechtse overtuigingen.

Naast het tot uiting brengen van extreemrechtse ideeën en identiteiten wordt er in wetenschappelijk onderzoek naar het gebruik van digitale mogelijkheden door extreemrechts nog een aantal verschillende doelen onderscheiden. Hierbij valt te denken aan het delen van extreemrechtse propaganda, (direct) communiceren met gelijkgestemden en het vormen van virtuele netwerken en gemeenschappen met een collectieve identiteit (Pauwels e.a. 2014, 55-61; Gerstenfeld e.a., 2003). De virtuele wereld wordt door extreemrechtse groeperingen bovendien gebruikt voor rekrutering (Perry \& Olsson, 2009), en ook voor de verkoop van producten, zoals merchandise of muziek (Gerstenfeld e.a., 2003). Bovendien kan het internet gebruikt worden om rechts-extremistisch geweld te verheerlijken of te bagatelliseren (NCTV, 2018b).

De online aanwezigheid van extreemrechts wordt in de wetenschappelijke literatuur aangeduid met de inwisselbaar gebruikte termen online of virtueel extremisme, online hate of cyberhate (zie o.a. Perry \& Olsson, 2009; Chetty \& Alathur, 2018). Online extremisme kan verschillende vormen aannemen, waaronder stereotypering, het toeschrijven van persoonlijke en maatschappelijke problemen aan een specifieke groep, maar ook 'advocating discrimination against a group, or advocating violence' (Hawdon e.a., 2018, 2). In deze voorbeelden lijkt er, net als in het onderzoek van De Koster en Houtman (2008) en andere studies naar extreemrechts op het internet, online geen sprake te zijn van het aanpassingsdi- 
lemma. Een select gezelschap op afgeschermde websites of fora - of iedereen met een internetverbinding wanneer het gaat om social media - krijgt zicht op extreemrechtse ideologieën, identiteiten en ideeën die tot uiting gebracht worden door zowel groeperingen als individuen. Dit overzicht van de wetenschappelijke literatuur roept de vraag op hoe extreemrechtse groeperingen in Nederland gebruik maken van social media.

\section{Methoden}

Om zicht te krijgen op de wijze waarop extreemrechtse groeperingen gebruik maken van social media zijn de berichten van drie groeperingen op diverse social media in het jaar 2017 geanalyseerd. In deze studie zijn de NVU, Pegida en Voorpost bestudeerd. De keuze voor deze drie groeperingen werd ingegeven door het feit dat zij ieder een andere categorie vertegenwoordigen van de ideologische ${ }^{5}$ overtuigingen van extreemrechtse groepen die in Nederland worden onderscheiden (Wagenaar, 2016, 43-48). Ten eerste zijn er in Nederland zogenaamde identitaire formaties, zoals het Identitair Verzet en Voorpost, die streven naar een ideaal van een homogeen Nederlands volk binnen het gebied waar dit volk historisch gezien is gevestigd. Ten tweede zijn er neonazistische formaties, zoals de NVU en Blood \& Honour, die het 'eigene' en het 'vreemde' definiëren vanuit biologisch-racistische kenmerken, waarbij het blanke ras biologisch superieur is aan andere rassen. Ten slotte zijn er de zogenaamde nieuwrechts-radicale formaties, zoals Pegida en Erkenbrand, die, in tegenstelling tot vorenstaande categorieën, geen uitgesproken identitair of neonaziprofiel hebben. Desondanks worden zij op basis van hun ideologie, activiteiten en achterban tot het extreemrechtse veld gerekend, temeer omdat zij een uitgesproken onderscheid op etnische gronden tussen het 'eigene' en het 'vreemde' hanteren, gecombineerd met een hang naar een meer autoritaire samenleving (Wagenaar, 2016, 43-48; 2017, 36-42).

In onze selectie van de drie extreemrechtse groeperingen zijn alle drie de voornoemde categorieën vertegenwoordigd. De specifieke keuze voor Voorpost, de NVU en Pegida is pragmatisch van aard geweest: tijdens de start van de dataver-

5 Naast ideologie worden er in de jaarlijkse rapportage 'Antisemitisme, racisme en extreemrechts geweld in Nederland' (Tierolf e.a., 2017) twee concepten gebruikt om naar het extreemrechtse gehalte van een organisatie te kijken. Met de indicator 'sociale genealogie' wordt beoordeeld in welke mate een (nieuwe) formatie voortkomt uit of onderdak biedt aan bekende extreemrechtse personen uit andere formaties (Van Donselaar, 1991). Extreemrechtse groeperingen ontstaan niet zomaar, maar komen meestal voort uit andere extreemrechtse formaties (Van Donselaar, 1991, 16-17). De 'magneetfunctie' heeft betrekking op de mate waarin bestaande organisaties zich aangetrokken voelen tot een nieuwe extreemrechtse speler (Wagenaar, 2016, 42), waarbij het van belang is in hoeverre zij aantrekkingskracht uitoefenen op personen die blijk hebben gegeven van uitgesproken extreemrechtse sympathieën (Davidović e.a., 2008, 170). Een laatste aanvullend en belangrijk element om extreemrechtse groeperingen te duiden is het zogenaamde tweeledige vijandbeeld (Wagenaar \& Van Donselaar, 2008, 20). Dit wil zeggen dat er aan de ene kant een afkeer is van de volksvreemden, daarmee wordt tegenwoordig veelal gedoeld op allochtonen in zijn algemeenheid. Daarnaast heeft volksvijandigheid betrekking op de afkeer van politieke tegenstanders. Hierbij kan het gaan om antifascistische activisten en demonstranten, maar ook om meer gevestigde politici en bestuurders. 
zameling bleken deze drie groeperingen het meest actief te zijn op socialmediaplatforms. De toegang tot de online omgevingen is verkregen zonder de accounts te liken of te volgen. De data die ten grondslag liggen aan deze bijdrage zijn voor iedereen met een internetverbinding openbaar, vandaar dat er geen noodzaak bestond tot het liken of volgen van de accounts.

Van de NVU en Voorpost zijn de officiële Facebookpagina's bestudeerd. Bij Pegida was dat niet mogelijk, aangezien de berichten van Pegida op Facebook niet volledig zichtbaar zijn. Na meermaals proberen en na navraag bij Pegida Nederland, door middel van een privébericht op Facebook, is duidelijk geworden dat de berichten van Pegida slechts zeven dagen zichtbaar zijn. Pegida heeft, naar eigen zeggen, dit besluit genomen om controle te hebben op hun berichten, aangezien er in het verleden misbruik is gemaakt van oudere berichten. Om voornoemde reden is ervoor gekozen om de berichten op Instagram en $\mathrm{VK}^{6}$ en een gedeelte van de berichten op Twitter te bestuderen.

Op 11 januari 2018 werd begonnen met het verzamelen van de berichten via social media. Omwille van de haalbaarheid is ervoor gekozen om alle berichten die door de NVU, Voorpost en Pegida in het jaar 2017 op hun socialmedia-accounts zijn geplaatst te verzamelen. Dit resulteerde in eerste instantie in een totaal van 1.511 berichten, die in de vorm van screenshots zijn opgeslagen. Van deze 1.511 berichten zijn diverse, overwegend dubbele berichten verwijderd. Bij de NVU waren er 76 berichten die al eerder waren gedeeld en diverse dubbele berichten waarin enkel een video is geplaatst of waarin iets te koop werd aangeboden. Deze zijn alle verwijderd en in totaal zijn er 627 berichten van de NVU meegenomen in dit onderzoek. Het aantal berichten van Pegida is teruggebracht door alle retweets te verwijderen. Er zijn 103 retweets verwijderd, waardoor er van de 185 berichten 82 berichten zijn meegenomen in dit onderzoek. De berichten van Pegida op Instagram (78) en VK (42) zijn alle meegenomen in de analyse. Van de 503 berichten van Voorpost zijn er 200 verwijderd. Voornamelijk dubbele berichten over verkooppromotie en herhaaldelijke uitnodigingen voor bijeenkomsten en evenementen zijn verwijderd. Uiteindelijk zijn enkel de berichten geselecteerd die door de drie groeperingen zelf zijn geplaatst op hun respectievelijke tijdlijnen. In totaal gaat dit om 1.132 berichten (zie tabel 1).

De 1.132 berichten zijn in verschillende fases geanalyseerd. In de eerste fase lag de nadruk op het segmenteren van de data en het toekennen van codes. Hierbij is onder andere gebruik gemaakt van thematische codes die werden ontleend aan de bestudeerde literatuur (Evers, 2015, 92), zoals haat, functies social media en geweld. $\mathrm{Na}$ deze eerste codeerfase zijn in de tweede fase analysetactieken ingezet om onder andere relaties tussen codes te leggen. Het ging hierbij om het lezen en herlezen van de geordende datasegmenten om het nader te kunnen duiden, maar ook om het toekennen van open codes aan de segmenten waar de deductieve codes geen of maar in beperkte mate recht deden aan het empirisch materiaal (Evers, 2015, 68). Zo werd de thematische code 'haat' in eerste instantie gebruikt

6 VK staat voor VKontakte, dit is een van oorsprong Russisch socialmediaplatform dat wereldwijd gebruikt wordt. 
Tabel 1 Aantal berichten meegenomen in het onderzoek

\begin{tabular}{llll}
\hline & NVU & Pegida & Voorpost \\
\hline Facebook & & & \\
Aantal berichten & 703 & & 503 \\
Aantal verwijderd & 76 & & 200 \\
$\begin{array}{l}\text { Twitter (periode 19 t/m } \\
\text { 3I december 20 I7) }\end{array}$ & & \\
Aantal tweets & 82 & \\
Aantal verwijderd (Retweets) & & 103 & \\
Instagram & & \\
Aantal berichten & 78 & \\
VK & & & \\
Aantal berichten & & 42 & 303 \\
Totaal & 627 & 202 & 1.132 \\
\hline
\end{tabular}

voor alle vormen en uitingen van haat en is dit in de tweede codeerfase gespecificeerd naar haat richting bepaalde groeperingen, zoals vluchtelingen, migranten en moslims. De resultaten van de eerste en tweede analysefase zijn vervolgens overstijgend met elkaar in verband gebracht (Evers, 2015, 120). Deze derde fase omvatte de nadere precisering van de bevindingen in de vorm van patronen, verschillen en overeenkomsten tussen de manieren waarop de drie extreemrechtse groeperingen gebruik maken van social media.

\section{Resultaten}

Onze analyse van de officiële socialmedia-accounts van de NVU, Pegida en Voorpost geeft zicht op drie overkoepelende manieren waarop deze groeperingen gebruik maken van sociale media: (1) het uitdragen van extreemrechtse ideologieën, (2) de constructie van een groepsidentiteit en (3) oproepen tot (democratische) vormen van verzet. Hiernaast blijkt uit onze analyse dat er in het gebruik van social media door de NVU, Pegida en Voorpost een online variant op het aanpassingsdilemma valt waar te nemen. Voordat we deze resultaten nader uitdiepen, beginnen we met een korte beschrijving van de drie extreemrechtse groeperingen, de hoeveelheid volgers en likes op social media en een schets van de inhoud van de berichten.

De extreemrechtse groeperingen op social media

- NVU: 'Lang leven de open grenzen'

De NVU is in 1971 opgericht en heeft zich in de jaren zeventig ontwikkeld tot een openlijk nationaalsocialistische partij met verzet tegen immigratie als belangrijk speerpunt (Van der Valk \& Wagenaar, 2010, 33; Wagenaar, 2017, 31). Omstreeks 1974 krijgt de NVU landelijke bekendheid. Vervolgens is er meerdere keren 
geprobeerd om de NVU te verbieden. Ondanks dat dit in eerste instantie is gelukt, is de NVU in beroep gegaan tegen dit verbod. De Hoge Raad heeft de NVU in het gelijk gesteld, waardoor de partij kon blijven voortbestaan. In de jaren tachtig stopte de NVU haar activiteiten, waarna zij in de jaren negentig opnieuw is opgericht (Wagenaar, 2017, 31).

Op de website ${ }^{7}$ van de NVU noemen zij zichzelf 'de radicaalste partij in Nederland die het volksnationalisme uitdraagt'. De NVU is, naar eigen zeggen, met een ongekende professionele opmars bezig en met een enorme groei van het aantal offline leden. Op socialmediaplatform Facebook heeft de NVU bij aanvang van de dataverzameling (11 januari 2018) 2.790 volgers en krijgt de Facebookpagina van de NVU 2.844 likes. De opmars die volgens de NVU offline valt waar te nemen, lijkt zich in mindere mate voor te doen op social media: het populairste bericht heeft 201 likes ontvangen. In dit bericht werd opgeroepen tot nationaal verzet naar aanleiding van een demonstratie van de actiegroep 'Kick Out Zwarte Piet', waarbij voorstanders van Zwarte Piet de weg hebben geblokkeerd.

De NVU wordt beschouwd als een zogenaamde neonazistische formatie, die het 'eigene' en het 'vreemde' definieert vanuit biologisch-racistische kenmerken, waarbij het blanke ras biologisch superieur is aan andere rassen (Wagenaar, 2016, 43-48). Afgaande op de berichten op social media lijkt 'de Nederlandse identiteit' een belangrijk onderwerp voor de NVU. Opmerkelijk genoeg wordt op basis van de berichten van de NVU maar in beperkte mate duidelijk waar de sociale constructie van 'de Nederlandse identiteit' uit is opgemaakt en waar het 'eigene' naar verwijst. Een uitzondering hierop is de oproep in meerdere berichten dat er een verbod zou moeten komen op het praten in vreemde talen op straat.

Wel besteedt de NVU meerdere berichten aan de sociale constructie van 'de Ander' (Geelhoed \& Siegel, 2016, 5) in de vorm van het tonen van de afkeer van het 'vreemde'. Meermaals bericht de NVU dat 'de Nederlandse identiteit' wordt aangetast door de komst van vreemdelingen, of dat nu (arbeids)migranten zijn of (oorlogs)vluchtelingen, iets dat met het nodige sarcasme gevangen wordt in: 'Lang leve de open grenzen!'F8 Daarnaast post de NVU in een bericht onder andere het volgende: 'Nog meer gelukszoekers, ja joh het kan niet op! De Nederlander hard werken en belasting betalen! De gelukszoekers van onze sociale voorzieningen profiteren en jaren in de bijstand ${ }^{\mathrm{F}}$. Ook richt de NVU zich meermaals specifiek op de islam, zoals: 'De haat tegen de radicale jihadistische islam, groeit met de seconde! Uitroeien dit addergebroed!'F

\section{- Pegida: '\#noislamjustfreedom'}

Pegida, medio 2015 opgericht in Duitsland en sinds het najaar van datzelfde jaar actief in Nederland, wordt gezien als een van de nieuwe rechts-radicale groepen. De afkorting staat voor 'Patriotische Europäer gegen die Islamisierung des Abend-

7 Zie http://nvu.info/geschiedenis.html, laatst bezocht op 21 juni 2019.

8 Letterlijke citaten zijn voorzien van een code om aan te geven van welk socialmediaplatform het bericht afkomstig is. F verwijst naar Facebook, T naar Twitter, I naar Instagram en V naar VK. Meerdere codes bij hetzelfde citaat wil zeggen dat het citaat letterlijk op dezelfde manier op verschillende platforms is geplaatst. 
landes' (Wagenaar, 2016, 47). Pegida richt zich, afgaande op teksten op de officiele website, ${ }^{9}$ voornamelijk tegen de komst en opvang van vluchtelingen, aangezien zij West-Europese volkeren wil beschermen tegen de bedreigingen die samenhangen met migratie. Een belangrijk speerpunt lijkt echter de toenemende islamisering te zijn. In het kader van dit onderzoek zijn meerdere socialmediaplatforms van Pegida bestudeerd. Op Facebook had de groepering tijdens de aanvang van de dataverzameling 6.008 likes en 6.360 volgers, op Twitter 9.379 likes en 3.271 volgers, op Instagram rond de 1.000 volgers en op VK 79 volgers. Het aantal volgers verschilt per platform, maar 231 is het meeste likes dat een bericht van Pegida op de verschillende socialmedia-accounts ontving. In dit bericht wenst Pegida 'alle Patriotten een gezond, gelukkig en strijdbaar $2018^{\text {'T }}$ en benoemt daarbij op weg te zijn naar 'een Islamvrij Nederland'T .

De afkeer van de islam die centraal staat in het acroniem Pegida komt ook prominent naar voren in de berichten op de socialmedia-accounts, waar het merendeel van de aandacht zich richt tegen de islam, zoals 'vrijheid eindigt waar islam begint', ${ }^{\text {I,V }}$. Ook met de terugkerende kreet '\#noislamjustfreedom' ${ }^{\text {T,I,V }}$ probeert Pegida tegenwicht te bieden aan de door haar ervaren islamisering en geeft ze aan Nederland islamvrij te willen maken. In de berichten worden verschillende elementen en associaties met de islam hevig bekritiseerd. Zo worden boerka's door Pegida aangeduid als 'vuilniszakken'I en een hoofddoek als een 'kopvod'T,I ${ }^{10}$ Dat Pegida geen blad voor de mond neemt om online haar afkeer te uiten van de islam, blijkt onder meer uit de volgende teksten: 'Fijne Pinksterdagen wensen wij alle niet Moslims, de Moslims wensen wij een Fuck Ramadan!\#Pegida', en 'Zoals altijd vieren weer vele moslims feest, omdat een aanhanger van Pedo Mohammed weer eens een terreur aanslag pleegde, ${ }^{\text {T,I }}$.

\section{- Voorpost: 'Wie islam zaait, zal sharia oogsten!'F}

De Vlaams-Nederlandse actiegroep Voorpost is in de jaren zeventig van de vorige eeuw opgericht. Voorpost vormt één organisatie in Vlaanderen en Nederland, waarbij er sprake is van een aparte structuur in de twee landen met twee voorzitters en twee actieleiders. Voorpost verzet zich tegen alle gepercipieerde 'bedreigingen' van het Nederlandse volk, die volgens haar voornamelijk bestaan uit immigratie, de islam en Amerikaanse culturele invloeden. Voorpost kent volgens Wagenaar (2016, 44-45) in Nederland een beperkt aantal activisten, weinig publieke activiteiten en geringe publieke belangstelling. Op social media lijkt dit echter anders te zijn en heeft Voorpost in vergelijking met de andere groeperingen de meeste likes en volgers: 8.754 likes en $8.625^{11}$ volgers tijdens de aanvang van de dataverzameling (11 januari 2018). De volgers van dit account lijken bovendien in vergelijking actiever dan de volgers op de accounts van de NVU en Pegida. Berichten van Voorpost werden veelvuldig geliket - waarbij het maximum-

9 Zie http://pegidanederland.com/, laatst bezocht op 21 juni 2019.

10 'Kopvod' is een term die o.a. door Geert Wilders is gebruikt en voorheen door andere extreemrechtse groeperingen is gehanteerd.

11 Wel dient hierbij opgemerkt te worden dat het niet enkel om volgers uit Nederland gaat, maar zij ook afkomstig (kunnen) zijn uit België. 
aantal likes dat een bericht kreeg 449 was - en gedeeld. In dat bericht is een afbeelding geplaatst over de verschillen tussen Zwarte Pieten in het jaar 1960 en 2017.

Wat betreft de inhoud van de berichten op social media lijkt Voorpost zich tussen de NVU en Pegida in te begeven. Voorpost gebruikt de berichten op haar socialmedia-accounts om haar afschuw van de multiculturele samenleving in zijn algemeenheid kenbaar te maken, maar zij benadrukt daarbij ook de problemen rondom de islam. Terrorisme is een van de onderwerpen die Voorpost aangrijpt om haar xenofobe standpunten kracht bij te zetten. Hierbij gebruikt zij veelvuldig de slogan 'Géén jihad in onze straat'F. Dat er terroristische aanslagen worden gepleegd, lijkt voor Voorpost een vanzelfsprekendheid door het politieke beleid dat binnen de EU wordt gevoerd: 'Wie islam zaait, zal sharia oogsten!'F

\section{'Kameraad'F: de constructie van een groepsidentiteit}

Het hiervoor geschetste overzicht van de aard van de berichtgeving geeft zicht op een eerste functie van social media: de online aanwezigheid wordt door de drie groeperingen gebruikt om hun respectievelijke ideologie uit te dragen en over te brengen. De socialmedia-accounts worden echter voor meer gebruikt dan enkel het eenzijdig zenden van informatie in de vorm van het communiceren van extreemrechtse ideeën en ideologieën. In hun analyse van het webforum Stormfront laten De Koster en Houtman (2008) zien dat onder de bezoekers van het forum een gevoel van gemeenschap en eenheid ontstaat. Ook op social media valt het construeren van een gemeenschap van gelijkgestemden en specifieke groepsidentiteiten waar te nemen. In de berichten op de door ons bestudeerde socialmedia-accounts komt dit op twee specifieke manieren tot uitdrukking. Ondanks dat het erop lijkt dat het merendeel van de personen uit deze online groepen elkaar nog nooit hebben ontmoet, kan er een zekere verbondenheid worden waargenomen en zelfs, zeker in combinatie met de uitgedragen extreemrechtse ideologieën op de respectievelijke socialmedia-accounts, een groepsidentiteit. Dit komt het meest prominent tot uitdrukking in het gehanteerde taalgebruik op social media. Bij de NVU wordt veelal gesproken over 'kameraad'F en 'volksgenoten die paraat

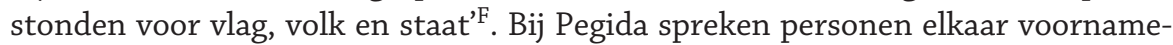
lijk aan met 'patriot', wat vaderlandslievend betekent. Bij Voorpost wordt, ten slotte, de term 'militanten' ${ }^{\mathrm{F}}$ gebruikt. Daarnaast is de term 'houzee' ${ }^{\mathrm{F}, \mathrm{T}}$, een strijdgroet die door de NSB is geïntroduceerd, door alle drie de groeperingen gebruikt. De groepsidentiteit komt daarnaast tot uitdrukking in het dragen van symbolen, zoals kenmerkende kleding met daarop de prinsenvlag afgebeeld of de tekst: 'Een hart voor eigen volk ${ }^{\mathrm{F}}$. Er valt bovendien een zekere marketing en commodificatie van de extreemrechtse ideologieën (Moufahim \& Humphreys, 2015) waar te nemen op social media: er worden sieraden te koop aangeboden, zoals een ketting met een hanger van een levensboom, oorbellen met de 'Algiz-rune' - een teken dat duidt op bescherming, maar ook werd gebruikt door de nazi's (Etter, 2001, 60-62) - en polsbandjes met daarop de tekst 'Onafhankelijkheid'F. Daarnaast worden dvd's, cd's, vlaggen en boeken onder de aandacht gebracht. Op social media verwijzen de NVU en Voorpost meermaals naar hun websites, waar eveneens diverse artikelen te koop worden aangeboden. Ook worden er posters 
verspreid met onder andere de volgende slogans: 'Handen af van onze tradities'F, 'Stop cultuurmarxisme'F, 'Stop ritueel slachten'F of 'Stop de EU-dictatuur!'F Pegida lijkt zich minder te richten op de verkoop van producten, maar zij gebruikt social media om donaties te verkrijgen voor de 'Stichting Vrienden van Pegida'. ${ }^{12}$ Bovendien wordt er op de socialmedia-accounts gecommuniceerd over aankomende meerdaagse kampen om activisten te 'vormen', stadswandelingen en informatie- en vormingsavonden ${ }^{13}$ die de groepsidentiteit van de volgers kunnen versterken.

\section{'Kom in verzet' ${ }^{\text {F }}$}

Naast het uitdragen van de ideologie en het construeren van een gevoel van gemeenschap worden de socialmedia-accounts ook gebruikt om volgers op te roepen in actie te komen. De NVU is voornamelijk actief met oproepen rondom de intocht van Sinterklaas, middels de slogan: 'Komt allen legaal in verzet!'F Daarnaast roept de NVU haar volgers op tot verzet met oneliners als: 'Baas in eigen land! Grenzen dicht nu!'F, 'NATIONAAL VERZET NU!'F, 'BREEK HET KOOSJERKARTEL!' ${ }^{\mathrm{F}}$ en 'Stop de multiculturele terreur!'F Ook Pegida roept met regelmaat op om haar acties te ondersteunen, zoals: 'Tijd voor de echte patriotten om in verzet te komen!'T , 'Laten we samen op 15 maart met onze stem de aftrap gaan geven, dat de islam uit Nederland word verdreven'I en 'Stop bouw MEGA moskee in Enschede met 25 meter hoge minaret! \#VERZET zal niet stoppen, meer \#acties zullen volgen!'I Naast de oproepen tot verzet lijkt Pegida vooral mensen uit te nodigen om bij een actie aanwezig te zijn: 'Wij nodigen je uit om morgen aanwezig te zijn', ${ }^{\text {IV }}$ of 'Kom je ook morgen?'I,V

Voorpost probeert haar volgers te activeren door meermaals te berichten over verzet middels slogans als '\#Kominverzet'F en 'Kom met Voorpost in 't offensief!' , of de kreet 'Blijf niet kalm sta op en herover jouw land!'F Het merendeel van de online oproepen heeft betrekking op offline acties die door de groeperingen worden georganiseerd en waarmee wordt getracht de offline aanhang te vergroten. Daarbij lijkt dat het aantal online volgers niet overeenkomt met de offline aanwezigheid van sympathisanten. Online hebben de groeperingen een groot aantal volgers, die meermaals de bereidheid hebben uitgesproken om in actie te komen. Offline blijft het activisme echter beperkt. Alle drie de groeperingen geven op social media aan dat het geen zin heeft om enkel online te sympathiseren met extreemrechtse groeperingen: mensen dienen ook daadwerkelijk offline en fysiek in actie te komen. Het volgende bericht, geplaatst door Voorpost, is wat dat betreft illustratief: 'Bij iedere aanslag een kaarsje opsteken, je profielfoto veranderen en meelopen in door de overheid georganiseerde protestmarsen helpt niet... kom uit je luie zetel en kom zelf in verzet!'F

12 Deze stichting is op 9 februari 2018 opgericht met het doel om Pegida Nederland te ondersteunen, door merchandising en het verkopen van artikelen met relevantie voor de doelstellingen, het organiseren van activiteiten en het financieel bijdragen aan de gemaakte kosten voor de organisatie, acties en demonstraties.

13 Een van de vormingsavonden had betrekking op de rechten en plichten van Voorpostactivisten tijdens acties en betogingen. Tijdens deze vormingsavond werd informatie gedeeld over de wijze waarop men actie moet voeren, over aanhoudingen en het gebruik van social media. 


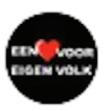

\section{Voorpost}

17 december 2017 om 13:33

\section{${ }^{* * *}$ persmededeling ${ }^{* * *}$ Voorpost patrouilleert in Hoek van Holland op zoek naar illegalen}

Voorpost is op straat als de politiek verzaakt! Geen maatregelen tegen immigratie en illegaliteit op de afgelopen EU-top?! Geen actie door de gevestigde politieke partijen?! Geen gehoor geven aan de problemen van de gewone burger?!

Dan ondernemen wij zelf actie! Illegaliteit = criminaliteit.

\section{Kom met Voorpost in 't offensief!} http://www.voorpost.org/.../voorpost-patrouilleert-in-hoek-v.../

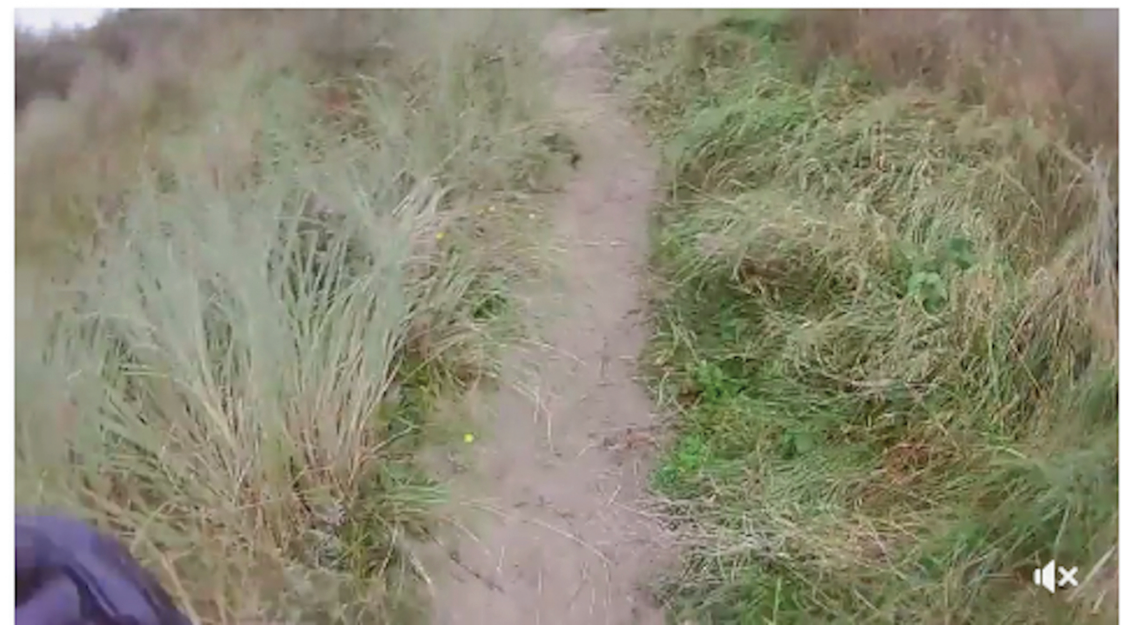

\section{Figuur 1 Bericht van Voorpost op Facebook}

Ondanks dat de groeperingen oproepen om vreedzaam actie te voeren, hebben sommige acties een provocerend karakter. De patrouilles die Voorpost zou hebben uitgevoerd in de duinen van Hoek van Holland op zoek naar illegalen, zoals is weergegeven in figuur 1, kunnen als provocerend worden beschouwd, nog ongeacht of deze patrouilles daadwerkelijk hebben plaatsgevonden. Bij dit bericht heeft Voorpost een video geplaatst waarin te zien is dat mannen met banden van Voorpost om hun armen door de duinen lopen en bunkers doorzoeken. De afsluiting van de video is: 'Nieuwsgierig geworden of heb jij ook het gevoel dat Nederland jouw land niet meer is? Sluit je dan bij ons aan en kom in verzet!'F 


\section{Het aanpassingsdilemma online}

Alle drie de extreemrechtse groeperingen gebruiken hun accounts om hun ideologie uit te dragen. De berichten van de drie extreemrechtse groeperingen lijken daarbij maar in beperkte mate expliciete uitingen van haat te bevatten. Dit lijkt niet zozeer het gevolg van het aanpassingsdilemma en het feit dat de NVU, Pegida en Voorpost hun vreemdelingenhaat of xenofobische standpunten online niet (willen) uitdragen, maar dient eerder gezien te worden als het product van de gebruikersvoorwaarden van de verschillende socialmediaplatforms. Ben-David en Matamoros-Fernández $(2016,1168)$ stellen immers dat: '[f]or extremists, then, the use of social media platforms such as Facebook means that they must adapt their practices to the platforms' terms of use'. Dit betekent onder andere dat het plaatsen van berichten niet op een anonieme manier kan gebeuren, maar ook dat gebruikers van socialmediaplatforms zich moeten houden aan de regels van Twitter ${ }^{14}$ of van de 'community' van Facebook:

'We definiëren haatdragend taalgebruik als een directe aanval op mensen op basis van wat we beschermde kenmerken noemen: ras, afkomst, nationaliteit, religie, seksuele geaardheid, kaste, sekse, geslacht, genderidentiteit, of ernstige ziekten of beperkingen. We bieden ook bescherming voor immigratiestatus. We definiëren een aanval als gewelddadig of mensonterend taalgebruik, beweringen over minderwaardigheid en oproepen tot uitsluiting of segregatie.' (https://nl-nl.facebook.com/communitystandards/objectionable _content)

In de gebruikersvoorwaarden wordt bovendien geëxpliciteerd dat de technologiebedrijven zo veel mogelijk proberen om potentiële offline schade te beperken, onder andere door het actief verwijderen van haatdragend taalgebruik dat aanzet tot ernstig geweld, of het verwijderen van accounts.

Ondanks dat sommige van de berichten op de officiële accounts van de NVU, Pegida en Voorpost in deze bijdrage wel degelijk vallen aan te merken als haatdragend taalgebruik conform vorenstaande definitie, lijkt het merendeel van de geplaatste digitale content zich te hebben geschikt naar de gebruikersvoorwaarden van de respectievelijke platforms. De extreemrechtse ideologie wordt daarmee online niet verhuld, maar de vorm van de boodschap en het taalgebruik lijken wel te worden aangepast. Dit wordt in het bijzonder duidelijk wanneer de berichten vergeleken worden met de reacties op de posts op de officiële socialmediaplatforms: de reacties zijn vele malen extremer en radicaler te noemen. De heftige aard van deze uitingen kan worden geillustreerd door de reactie op een bericht over een persoon met een donkere huidskleur die vermoedelijk een strafbaar feit had gepleegd, en resulteert in reacties als: 'tyfus hond', 'kut slaaf' ${ }^{\text {I }}$ en 'vuile kanker aap'I. Onder berichten over de islam en moslims vallen reacties te lezen als 'Moslim tuig' ${ }^{\mathrm{F}, \mathrm{T}}$, 'ziek volk'T , 'onkruid'T, 'Altijd weer die kut islam wat voor problemen zorgd... gewoon bom erop en opgeruimd staat netjes' ${ }^{\text {T }}$. 
Naast de scheldwoorden en expliciete beledigingen bevatten de reacties ook gewelddadige verwijzingen: 'Aan de auto vastbinden en meeslepen', 'Volgende keer tussen de ogen mikken', 'In het zwavelzuur ermee anders blijft er nog zwerfvuil achter ook' ${ }^{\mathrm{F}}$, 'Een autoband rond zijn nek en in brand steken'F, 'Hopelijk verzuipen $z \mathrm{e}^{\text {'F }}$ of 'Afschieten is de beste oplossing'F. Aan de ene kant kan in deze verharding het 'online disinhibition effect' (Suler, 2004) worden herkend, waarbij de (gepercipieerde) anonimiteit van de socialmediagebruikers bijdraagt aan extreme en gewelddadige reacties op het internet, zoals bijvoorbeeld ook op nieuwsberichten op websites van kranten en andere nieuwsoutlets valt waar te nemen (zie o.a. Ciftci e.a., 2017). Aan de andere kant kunnen deze specifieke reacties niet los worden gezien van de context: ze worden immers geplaatst onder berichten van de NVU, Pegida en Voorpost. Dergelijke berichten hoeven, zoals figuur 2 van de NVU illustreert, ${ }^{15}$ op zichzelf niet provocerend van aard te zijn.

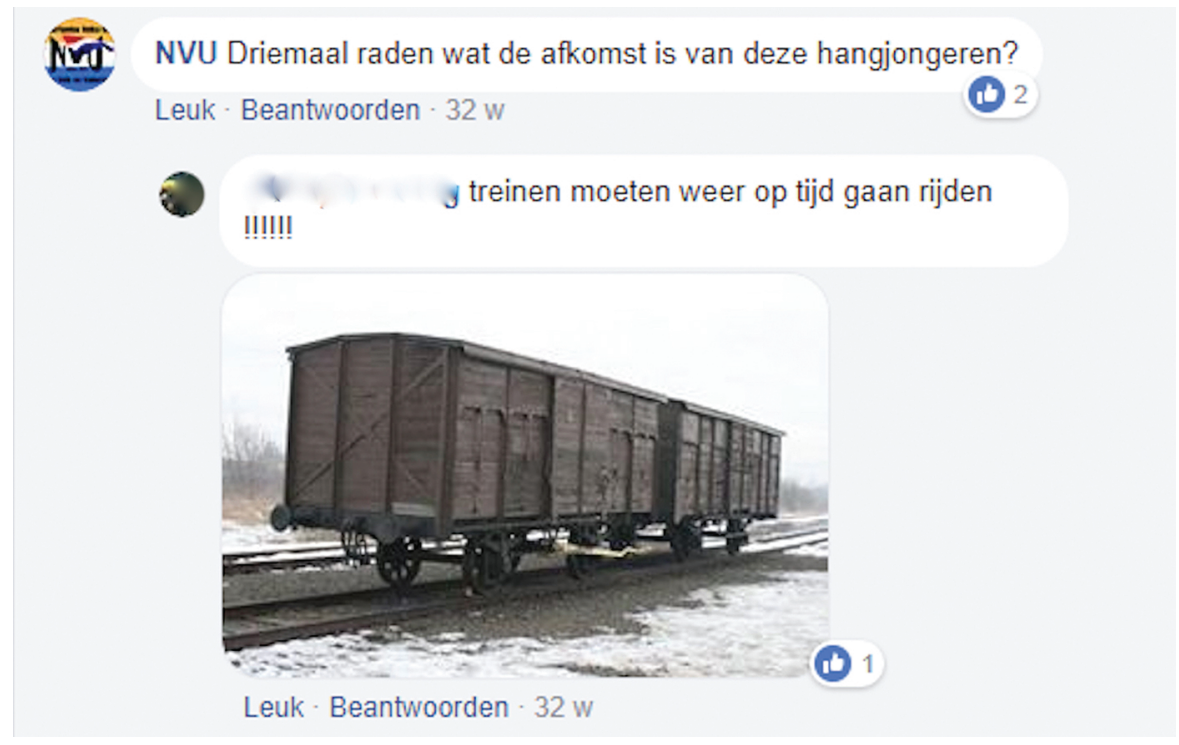

Figuur 2 Reacties op een bericht van de NVU op Facebook

Ook de reacties op de berichten over geweldloze vormen van verzet tonen zich aanzienlijk extremer. Daarin springt met name in het oog dat (enkele) volgers teleurgesteld zijn in de democratische vormen van politiek verzet en dat zijzelf in actie moeten komen, omdat er 'zonder brutaal geweld niks zal veranderen'F. In deze reacties op een tweet (figuur 3) van Pegida wordt dit eveneens geïllustreerd:

15 Wetenschappelijk onderzoek naar het gebruik van social media roept een aantal nieuwe ethische dilemma's op (Shlovski \& Vertesi, 2012). Omdat online content in deze bijdrage centraal staat, hebben we er niet voor gekozen om alle digitale statements 'ungoogleable' te maken, in het bijzonder omdat hiermee een groot deel van het betekenisvolle empirische materiaal verloren zou gaan. Wel hebben we gebruikersnamen, met uitzondering van de NVU, Voorpost en Pegida, onherkenbaar gemaakt om directe herleidbaarheid en identificatie te voorkomen. 


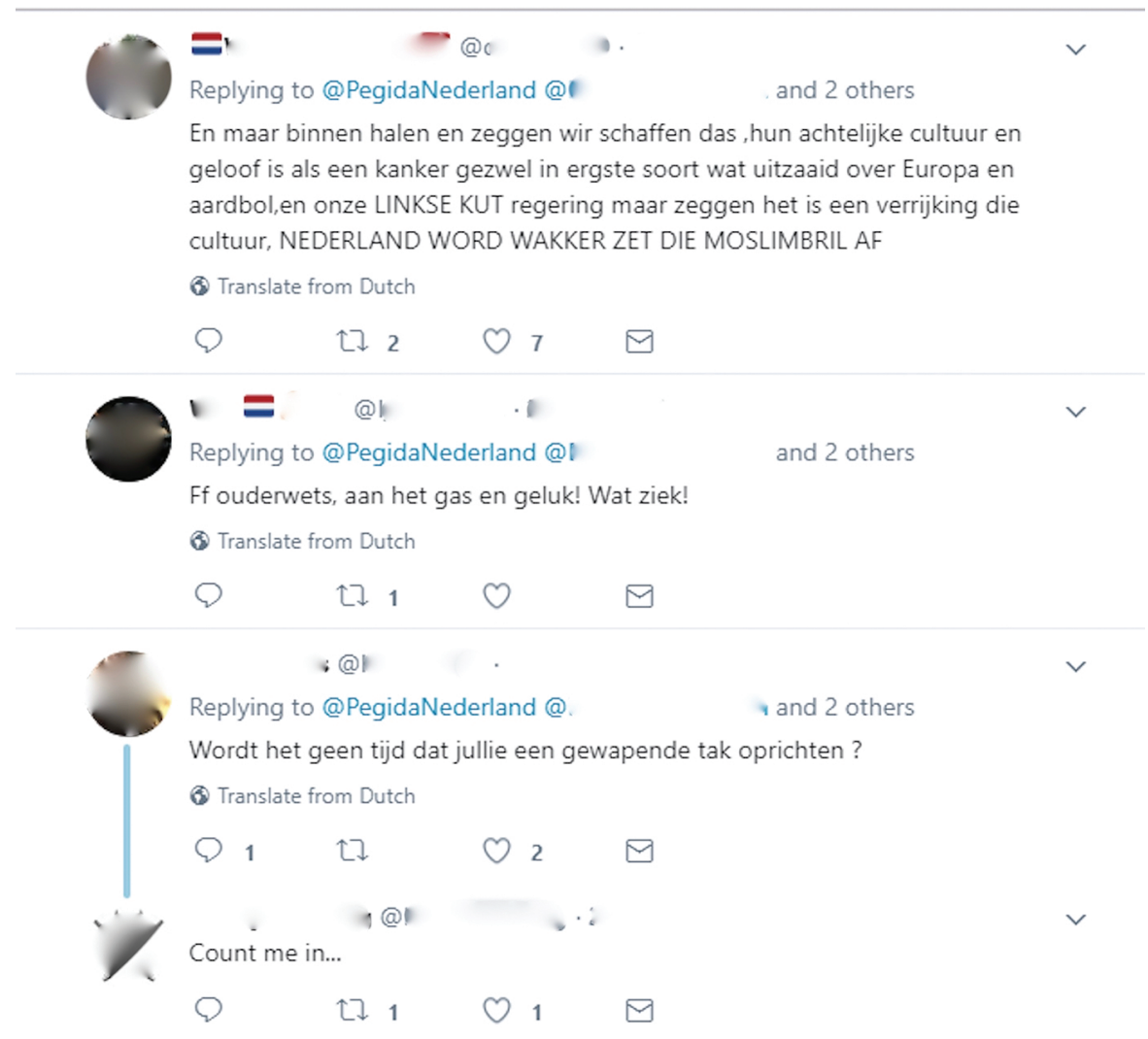

Figuur 3 Reacties op een tweet van Pegida

Ook andere reacties bevatten expliciete oproepen om het heft in eigen handen te nemen, zoals de volgende reactie op een bericht van de NVU op Facebook: 'Ik denk dat we ons zelf maar moeten beveiligen wat van deze overheid hoef je niets te verwachten DUS NEDERLANDERS KOOP WAPENS EN BESCHERM JEZELF EN JE FAMILIE'F.

Ondanks dat er in deze reacties niet gesproken kan worden van het aanpassingsdilemma, tonen (enkele) volgers zich wel degelijk bewust van de eventuele consequenties van deze posts, zoals blijkt uit de volgende reactie op een bericht van Voorpost op Facebook: 'Wij moeten onze mond maar houden overheid speurd het internet af naar racisten op risico van vervolging ik denk niet dat dit goed blijft aflopen'F. In het geval dat berichten namelijk dermate aanstootgevend zijn, kan, naast dat de content wordt verwijderd, door Facebook en Twitter ook contact worden gezocht met de autoriteiten. Bovendien maken overheidsdiensten in toenemende mate gebruik van social media in de opsporingspraktijk (Custers \& Vergouw, 2016). Opvallend is dat de persoonlijke gegevens van diverse volgers openlijk zichtbaar zijn. Op Facebook plaatsen mensen in het bijzonder hun (eigen) naam en foto. Op Instagram en Twitter wordt meermaals gebruik gemaakt van 
aliassen; in de gebruikersnamen zijn termen genoemd als 'blond', ${ }^{\text {T,I }}$, "blank ${ }^{\text {T,I }}$ of 'Nederland'T,I met daarbij de Nederlandse vlag of de tekst 'waard om voor te knokken'T.

Een aantal volgers geeft in de reacties aan ondervonden te hebben dat het plaatsen van aanstootgevende reacties kan resulteren in het geblokkeerd of verwijderd worden van Facebook. Dit lijkt menig volger echter niet af te schrikken, aangezien er gemakkelijk een ander account kan worden aangemaakt op hetzelfde platform of er overgestapt kan worden naar een ander socialmediaplatform. Op Twitter wordt er om die reden verwezen naar Gab.ai, een van oorsprong Amerikaans socialmediaplatform waar de vrijheid van meningsuiting centraal staat. Gab.ai wordt beschouwd als een aantrekkelijke online omgeving om extreemrechts gedachtegoed te verspreiden (Zannettou e.a., 2018; Roose, 2018). Het idee heerst, zoals blijkt uit het bericht hierna, dat op Facebook en Twitter niet (langer) openlijk een mening kan worden geuit: 'Wegens steeds meer censuur op Twitter en Facebook, zijn we vanaf vandaag ook uit voorzorg actief op Gab.ai!'T

\section{Discussie}

Deze verkennende studie illustreert dat het gebruik van social media door groeperingen als de NVU, Pegida en Voorpost ertoe leidt dat extreemrechtse groeperingen niet langer enkel actief zijn in de marges en krochten van het internet, zoals 4chan of Stormfront, maar zichtbaar en openlijk op mainstream-socialmediaplatforms (vgl. Winter, 2019). Onze eerste onderzoeksvraag richtte zich op het gebruik van social media door de drie extreemrechtse groeperingen. We zien daarbij allereerst dat voor zowel de NVU als Pegida en Voorpost social media een rol spelen in het uitdragen van hun respectievelijke ideologieën. Hierbij valt op dat de ideologische verschillen tussen deze drie groeperingen die in de literatuur worden benoemd (o.a. Moors e.a., 2009; Wagenaar, 2016; 2017), in de berichten op social media meer fluïde lijken te zijn (vgl. AIVD, 2018). Ondanks dat de meer 'klassieke' extreemrechtse groeperingen, zoals de NVU en Voorpost, breder georienteerd zijn op alles wat 'vreemd' is, speelt de afkeer van de islam een centrale rol in de geplaatste berichten. Sterker nog, op de door ons bestudeerde socialmediaplatforms lijkt er sprake te zijn van 'moslim- of islampaniek' en wordt de islam op zowel sociaal als cultureel en moreel vlak beschouwd als 'dé meest complete belichaming van deze hedendaags als bedreigend ervaren veranderingen in Nederland' (Bouabid, 2018, 311).

Het construeren van een groepsidentiteit kan gezien worden als de tweede manier waarop de drie door ons bestudeerde groeperingen gebruik maken van social media. In de bestudeerde berichten komt dit tot uitdrukking in de vorm van specifieke gedeelde termen en kreten, kleding, maar ook uitnodigingen en oproepen tot offline gezamenlijke verbindende activiteiten. Hiermee kan het online gedrag op social media voor (actieve) volgers resulteren in een vergelijkbaar gemeenschapsgevoel of 'sense of belonging' als op internetfora zoals Stormfront (De Koster \& Houtman, 2008). Naast deze groepsidentiteit en de eerder genoemde ideologische informatiedeling zien we, ten derde, dat de drie groepe- 
ringen social media gebruiken om hun volgers te mobiliseren (vgl. NCTV, 2018a, 20), een tactiek die voort lijkt te bouwen op zowel de dreiging voor als de haat tegen 'de Ander', die centraal staan in zowel de extreemrechtse ideologieën als de geconstrueerde groepsidentiteit. In de berichten worden volgers nadrukkelijk opgeroepen om hun activiteiten niet te beperken tot het bekijken, liken en sympathiseren met extreemrechts gedachtegoed, maar de (offline) daad bij het (online) woord te voegen.

De tweede vraag die we in deze studie hebben geprobeerd te beantwoorden, was: in hoeverre kan er op de door ons bestudeerde socialmedia-accounts gesproken worden van online extremisme? Ondanks dat de contouren van het zaaien van haat en het demoniseren van bepaalde bevolkingsgroepen en religieuze gemeenschappen wel degelijk vallen waar te nemen in de berichten van de NVU, Pegida en Voorpost (vgl. AIVD, 2018, 15), springen niet zozeer de extreme berichten in het oog, maar eerder de overwegend gematigde toon van het grootste deel van de digitale content. Onze studie illustreert hiermee dat het aanpassingsdilemma van extreemrechts ook een digitale equivalent kent, maar online wel een andere invulling krijgt dan offline. De extreemrechtse ideologieën en ideeën worden op social media niet per definitie verhuld: alle drie de groeperingen expliciteren in de door ons bestudeerde berichten immers hun afkeer van of haat jegens bepaalde (etnische) groepen. Wel lijkt zowel de vorm als de inhoud van uitingen van vreemdelingenhaat of xenofobische standpunten afgestemd te worden op de gebruikersvoorwaarden van de socialmediaplatforms, zoals eerder ook werd waargenomen in een analyse van het webforum Stormfront (Bowman-Grieve, 2009, 1003). Deze aanpassing aan de regels van de online omgeving dient ervoor te zorgen dat berichten niet van Facebook of Twitter worden verwijderd, of erger: dat accounts geblokkeerd of verwijderd worden door beheerders van de platforms of dat zij de autoriteiten op de hoogte stellen van de geplaatste content. In het online aanpassingsdilemma lijkt het dus niet zozeer te gaan om impression management à la Goffman, maar eerder om content management om ervoor te zorgen dat de extreemrechtse ideologieën via social media blijvend kunnen worden uitgedragen, zij het op gematigde toon.

Het online aanpassingsdilemma lijkt niet van toepassing te zijn op de reacties op de berichten van de NVU, Pegida en Voorpost. Onze resultaten tonen dat de (anonieme) reacties vele malen extremer, radicaler en gewelddadiger van aard zijn dan de initiële posts van de drie extreemrechtse groeperingen. Opmerkelijk is dat deze reacties lang niet altijd verwijderd worden, noch door beheerders van de socialmediaplatforms zelf, noch door moderators van de officiële accounts van de NVU, Pegida en Voorpost, die ook beschikken over dergelijke beheerdersrechten. De NCTV $(2018 a, 28)$ stelt in zijn meest recente rapportage over de toename van rechts-extremistisch geweld in West-Europa dat moderators 'in enkele gevallen' de reactie onder het bericht 'waarin het geweld wel expliciet wordt goedgekeurd of waarin wordt opgeroepen tot gelijksoortige acties' laat staan. Onze studie illustreert echter dat dit niet beperkt blijft tot enkele gevallen. De gevolgen van het laten staan van deze reacties, in het bijzonder onder de berichten van extreemrechtse groeperingen, verdienen bijzondere aandacht. Expliciete uitingen van haat of oproepen tot geweld op social media kunnen, zoals het eerdere onderzoek 
van Pauwels en collega's (2014) ook illustreerde, een voedingsbodem vormen voor polarisatie en radicalisering, maar ook voor offline vormen van geweld (NCTV, 2018a).

We besluiten deze bijdrage met het nader duiden van het gebruik van social media door de door ons bestudeerde extreemrechtse groeperingen. Wanneer met enige distantie naar de resultaten van deze studie wordt gekeken, kan worden betoogd dat de manier waarop de NVU, Pegida en Voorpost gebruik maken van social media gezien zou kunnen worden als de online equivalent van de manifestaties van extreemrechts in het publieke domein. Online zien we immers de permanente aanwezigheid van extreemrechts en een daarmee gepaard gaande aanhoudende stroom van specifieke standpunten en ideologieën. Het bereik hiervan is echter vele malen groter dan de traditionele vormen als 'demonstraties, publieke protestbijeenkomsten of bijvoorbeeld het uitdelen van pamfletten op straat' (Tierolf e.a., 2017, 44). Een bijkomend voordeel is dat online demonstraties, anders dan de klassieke offline variant, niet resulteren in vechtpartijen of de arrestatie van (gezichtsbepalende) personen uit de organisatie (NRC, 2019). Social media worden daarnaast gekenmerkt door de 'persistence, visibility, spreadability and searchability' (boyd, 2014, 11) van de content. Op een laagdrempelige, eenvoudige manier kan een groot onbekend publiek worden bereikt. Bovendien kan, zeker wanneer de groeperingen zich conformeren aan de gebruikersvoorwaarden van de socialmediaplatforms, op een relatief ongestoorde manier de extreemrechtse ideologie worden uitgedragen. Het bereik en de impact van de boodschap van de drie extreemrechtse groeperingen kunnen daarmee via social media vergroot worden. In de onderhavige studie lijkt Voorpost hiervan een voorbeeld te zijn.

Een belangrijke kanttekening is dat we hier te maken hebben met een verkennende studie die zich beperkt tot (een selectie van) de berichten en reacties op social media van drie extreemrechtse groeperingen in het jaar 2017. Ondanks dat deze resultaten zicht geven op de aanwezigheid van extreemrechtse ideeën op de officiële socialmedia-accounts van de NVU, Pegida en Voorpost, dient - analoog aan wat Van der Valk en Van der Schans $(2011,12)$ beschrijven ten aanzien van het analyseren van openbare boodschappen van (potentieel) extreemrechtse organisaties - opgemerkt te worden dat het definiëren van de extreemrechtse ideologie van deze groeperingen op basis van alleen het socialmediagebruik niet voldoende houvast biedt. Om de vorm, inhoud en betekenis van online extremisme in Nederland beter te beschrijven en te kunnen verklaren is nader onderzoek vereist. Behalve de socialmediaplatforms, zoals in de onderhavige studie, lenen ook YouTube (vgl. Roose, 2019) en het eerder genoemde platform Gab.ai zich voor een nadere analyse van digitale (uitings)vormen van rechts-extremisme. Naast aandacht voor de aard van het fenomeen, dient ook de aanpak door socialmediabedrijven, opsporingsdiensten en overheden van deze openbaar zichtbare informatie in vervolgonderzoek nader belicht te worden. 


\section{Literatuurlijst}

AIVD (2018). Rechts-extremisme in Nederland. Een fenomeen in beweging. Den Haag: Algemene Inlichtingen- en Veiligheidsdienst.

Ben-David, A. \& Matamoros-Fernández, A. (2016). Hate speech and covert discrimination on social media. Monitoring the Facebook pages of extreme-right political parties in Spain. International Journal of Communication, 10(3), 1167-1193.

Bouabid, A. (2018). De Marokkanenpaniek; een geïntegreerde morele paniekbenadering van het stigma 'Marokkaan' in Nederland. Den Haag: Boom criminologie.

Bowman-Grieve, L. (2009). Exploring 'Stormfront': a virtual community of the radical right. Studies in Conflict \& Terrorism, 32(11), 989-1007.

Boyd, D. (2014). It's complicated. The social lives of networked teens. New Haven: Yale University Press.

Caiani, M. \& Kröll, P. (2015). The transnationalization of the extreme right and the use of the Internet. International Journal of Comparative and Applied Criminal Justice, 39(4), 331-351.

Chetty, N. \& Alathur, S. (2018). Hate speech review in the context of online social networks. Aggression and Violent Behavior, 40, 108-118.

Ciftci, T., Gashi, L., Hoffmann, R., Bahr, D., Ilhan, A. \& Fietkiewicz, K. (2017, July). Hate speech on Facebook. In: Proceedings of the 4th European Conference on Social Media, ECSM 2017 (pp. 425-433). Sonning Common: Academic Conferences and Publishing International Ltd.

Custers, B. \& Vergouw, B. (2016). Technologie voor opsporing en handhaving. Justitiële verkenningen, 42(3), 48-67.

Davidović, M., Donselaar, J. van, Rodrigues, P.R., \& Wagenaar, W. (2008). Het extreemrechtse en discriminatoire gehalte van de PVV. In J. van Donselaar \& P.R. Rodrigues (eds.). Monitor Racisme \& Extremisme. Achtste rapportage (pp. 167-190). Amsterdam: Anne Frank Stichting/Amsterdam University Press.

De Waele, M. (2013). Rechts-extremistische groeperingen in Vlaanderen. Cahier Integrale Veiligheid, 39(105), 3-34.

Donselaar, J. van (1991). Fout na de oorlog: fascistische en racistische organisaties in Nederland 1950-1990. Amsterdam: Bert Bakker.

Donselaar, J. van (2009). Rechts radicalisme. In: H. Moors, L. Balogh, J. van Donselaar \& B. de Graaff (eds.). Polarisatie en radicalisering in Nederland. Een verkenning van de stand van zaken in 2009. Tilburg: IVA, 77-97.

Etter, G. (2001). Totemism and symbolism in the white supremacist movements. Images of an urban tribal warrior culture. Journal of Gang Research, 8, 49-75.

Evers, J. (2015). Kwalitatieve analyse: kunst én kunde. Amsterdam: Boom Lemma uitgevers.

Geelhoed, F. \& Siegel, D. (2016). The other: een introductie. Tijdschrift over Cultuur \& Criminaliteit, 2016(1), 3-9.

Gerstenfeld, P.B., Grant, D.R. \& Chiang, C.P. (2003). Hate online: a content analysis of extremist Internet sites. Analyses of Social Issues and Public Policy, 3(1), 29-44.

Goffman, E. (1959). The presentation of self in everyday life. New York: Doubleday.

Hawdon, J., Bernatzky, C. \& Costello, M. (2018). Cyber-routines, political attitudes, and exposure to violence-advocating online extremism. Social Forces. https://doi.org/ $10.1093 /$ sf/soy115.

Hawley, G. (2017). Making sense of the alt-right. New York: Columbia University Press.

Koster, W. de \& Houtman, D. (2008). 'Stormfront is like a second home to me.' On virtual community formation by right-wing extremists. Information, Communication \& Society, 11(8), 1155-1176. 
Moors, J., Balogh, L., Donselaar, J. van \& Graaff, B. de (2009). Polarisatie en radicalisering in Nederland. Een verkenning van de stand van zaken in 2009. Tilburg: IVA.

Moufahim, M. \& Humphreys, M. (2015). Marketing an extremist ideology. The Vlaams Belang's nationalist discourse. In: A. Pullen \& C. Rhodes (eds.). The Routledge companion to ethics, politics and organizations. Oxon: Routledge, 85-99.

Mudde, C. (1995). Right-wing extremist parties. European Journal of Political Research, 27(2), 203-224.

Nagle, A. (2017). Kill all normies. Online culture wars from 4chan and Tumblr to Trump and the alt-right. Winchester: Zero Books.

NCTV (2018a). De golfbewegingen van rechts-extremistisch geweld in West-Europa. Aard, ernst en omvang van de rechts-extremistische geweldsdreiging in West-Europa, inclusief Nederland. Den Haag: Nationaal Coördinator Terrorismebestrijding en Veiligheid.

NCTV (2018b). Dreigingsbeeld terrorisme Nederland. Den Haag: Nationaal Coördinator Terrorismebestrijding en Veiligheid.

NRC (2019, 24 juni). Pegida-betoging onderbroken. Gevonden op www.nrc.nl/nieuws/ 2019/06/24/aanhoudingen-pegida-betoging-onderbroken-a3964785. Laatst geraadpleegd op 24 juni 2019.

Pauwels, L., Brion, F., Schils, N., Laffineur, J., Verhage, A., De Ruyver, B. \& Easton, M. (2014). Explaining and understanding the role of exposure to new social media on violent extremism: an integrative quantitative and qualitative approach. Gent: Academia Press.

Perry, B. \& Olsson, P. (2009). Cyberhate: the globalization of hate. Information \& Communications Technology Law, 18(2), 185-199.

Picca, L. \& Feagin, J. (2007). Two-faced racism. Whites in the backstage and frontstage. New York: Routledge.

Roose, K. (2018, 28 October). On Gab, an extremist-friendly site, Pittsburgh shooting suspect aired his hatred in full. The New York Times. Retrieved October 22, 2019 from www.nytimes.com/2018/10/28/us/gab-robert-bowers-pittsburgh-synagogueshootings.html.

Roose, K. (2019, 8 June). The making of a YouTube radical. The New York Times. Retrieved June 14, 2019 from www.nytimes.com/interactive/2019/06/08/technology/youtuberadical.html.

Shklovski, I. \& Vertesi, J. (2012). 'Un-googling' research technologies, communities at risk and the ethics of user studies in HCI. Retrieved September 1, 2019 from https://core.ac.uk/ download/pdf/50527275.pdf.

Suler, J. (2004). The online disinhibition effect. Cyberpsychology \& Behavior, 7(3), 321-326.

Tierolf, B., Kapel, M. van \& L. Drost m.m.v. W. Wagenaar (2017). Zesde rapportage racisme, antisemitisme en extreemrechts geweld in Nederland. Incidenten, aangiftes, verdachten en afhandeling in 2016. Utrecht: Verwey-Jonker Instituut.

Tierolf, B., Drost, L. \& Kapel, M. van, m.m.v. W. Wagenaar (2018). Zevende rapportage racisme, antisemitisme en extreemrechts geweld in Nederland. Incidenten, aangiftes, verdachten en afhandeling in 2017. Utrecht: Verwey-Jonker Instituut.

Valasik, M. \& Reid, S.E. (2018). Alt-right gangs and white power youth groups. Oxford Bibliographies Online: Criminology. doi:10.1093/OBO/9780195396607-0243.

Valk, I. van der \& Wagenaar, W. (2010). Monitor Racisme \& Extremisme. In en uit extreemrechts. Amsterdam: Anne Frank Stichting/Amsterdam University Press.

Valk, I van der \& W. van der Schans (2011). Monitor Racisme \& Extremisme. Extreemrechts in Amsterdam. Amsterdam: Anne Frank Stichting/Amsterdam University Press.

Wagenaar, W. (2016). Extreemrechtse formaties en extreemrechts geweld. In: B. Tierolf, N. Hermens, M. van Kapel \& W. Wagenaar, Racisme, antisemitisme en extreemrechts geweld in Nederland. Vijfde rapportage. Utrecht: Verwey-Jonker Instituut, 42-53. 
Wagenaar, W. (2017). Factsheet extreemrechts in Nederlandse gemeentes. Amsterdam: Anne Frank Stichting.

Wagenaar, W. \& Donselaar, J. van (2008). Racistisch en extreemrechts geweld in 2007. In: J. van Donselaar \& P.R. Rodrigues (eds.). Monitor Racisme \& Extremisme. Achtste rapportage. Amsterdam: Anne Frank Stichting, 17-41.

Winter, A. (2019). Online hate: from the far-right to the 'alt-right' and from the margins to the mainstream. In: K. Lumsden \& E. Harmer (eds.). Online othering exploring digital violence and discrimination on the web. Cham, Switzerland: Palgrave Macmillan, 39-63.

Zannettou, S., Bradlyn, B., De Cristofaro, E., Kwak, H., Sirivianos, M., Stringini, G. \& Blackburn, J. (2018). What is gab? A bastion of free speech or an alt-right echo chamber? In: A. Skarzauskiene \& N. Gudeliene (eds.). Companion of the The Web Conference 2018 on The Web Conference 2018, 1007-1014. 